\title{
“Websites Are More Helpful Because I Can Comeback": Students' Perspective on the Use of Learning Websites
}

\author{
Veni Nella Syahputri ${ }^{*}$, Endah Anisa Rahma ${ }^{2}$, Rusma Setiyana ${ }^{3}$ \\ ${ }^{1}$ Department of Public Administration, Faculty of Social and Political Science, \\ Universitas Teuku Umar, Aceh, Indonesia \\ ${ }^{2}$ Department of Marine Science, Faculty of Fisheries and Marine Sciences, \\ Universitas Teuku Umar, Aceh, Indonesia \\ ${ }^{3}$ Department of Management, Faculty of Economics, \\ Universitas Teuku Umar, Aceh, Indonesia
}

*Corresponding author: Veni Nella Syahputri; email: venninellasyahputri@utu.ac.id

\begin{abstract}
During the COVID-19 pandemic, the educational system has changed. This brought a significant shift to class and teaching management as well. Teachers manage their classes in various ways by utilizing digital platforms. This study aims at finding out students' perspective on using website in the teaching and learning process. This study was conducted by using qualitative approach design, with the descriptive case study method. There were 17 university students at Universitas Teuku Umar who were involved as the respondents in this study. In data collection, an interview set consisting of 6 questions was distributed to students. Later, the data were analyzed using interactive analysis through the three steps, which are data identification, data display, and data verification. The result shows that students have positive feedbacks toward the use of websites during online learning rather than other digital platforms. The reasons are the constant availability, length adequacy, and completeness. The implication of this study is that it is more preferrable for students to learn by using websites-or better known as e-learning system-rather than other platforms.
\end{abstract}

Keywords: learning websites, e-learning, positive feedback, digital classroom, COVID-19 pandemic.

\section{Introduction}

Currently, quite a lot of students are more interested in finding information from the internet than other media. Likewise, information related to learning materials. The limited availability of learning media in schools makes students more interested in using the internet as a learning resource (Syahputri et al., 2020).

Through the implementation of ICT, especially internet and website media, the learning process is expected to be more student-centered so that learning outcomes will increase. Teachers as learning facilitators must be able to provide facilities and media that make it easier for students to learn. Vocational teachers as educators must also be able to use and develop ICT professionally which is implemented in learning. The research results can be used as input to facilitate teachers and vocational students in the use of ICT, especially the internet and websites. For teachers, websites can be used as alternative learning media to improve student learning outcomes and ICT skills. Utilization of the website is expected to familiarize students to be active in learning so that learning is more 
student-centered. The results of the study can increase students' interest in using the website as a learning resource.

Learning media is a media that is specifically designed to stimulate the thoughts, feelings, attention, and willingness of students so that the learning process occurs. Learning media contains information that can be in the form of knowledge or become a means for students to carry out learning activities (reading, observing, trying, working on questions, answering questions, and others). Learning media is not just a physical object, but everything that already contains learning material, thus enabling someone to use it to learn in order to gain knowledge, skills, or change attitudes (Sahid, 2010). Media utilization is the systematic use of learning resources. The utilization of website function is very important because it discusses the relationship between students and learning materials or learning systems (Warsita, 2008). Some patterns of utilization of learning media (Furqan, 2012), namely: 1. Utilization of media in classroom situations or in the classroom, namely learning media are used to support the achievement of certain goals and their use is combined with the teaching and learning process in classroom situations; and 2 . The use of media outside the classroom situation or outside the classroom, including the free use, in a controlled manner, and the use of media individually, in groups or in groups.

The World Wide Web (www) also known as the web, site, website or site is an internet application and service that includes multimedia resources (Rusman et al., 2012). The physical web is a collection of personal computers, web browsers, connected to ISPs, server computers, routers, and switches that are used to stream information and become the first vehicle for various related parties (Oetomo et al., 2007). The types of websites that are used by students in this study are limited to search engines, blogs, web portals and corporate websites that are dynamic or static. Utilization of the internet network as a source and learning tool can be implemented as follows: 1. Browsing or surfing is a general term used when you want to explore the virtual world or the web. 2. Resourcing is to make the internet a teaching resource. The role of the internet as a repository of information is used to obtain information and data related to the teaching material delivered. Information relating to the address of the site to be visited as a source of teaching materials has been known in advance through the information provided in the teaching handbook and from other information.

In general, websites are divided into several types (Susanti \& Oriniati, 2020). Explanation of the types of websites used in this research, namely: 1. Web search engine is a web that has the ability to search documents based on certain keywords. Example: Google and all websites. 2. Web portal is a web that contains a collection of links, search engines, and information. Example: Yahoo and AOL.3.Company web is a web that describes a company, services, facilities, and everything about the company. 4. Weblog or often abbreviated as blog is an internet site that allows the owner to write down anything that becomes the user's opinion or views on something as well as a journal.

The learning process in students is something unique, occurs through planned efforts that result in behavioral changes. Learning outcomes can be in the form of changes in cognitive, affective and psychomotor abilities. Learning outcomes are changes in behavior due to learning. Learning outcomes are the achievement of educational goals for students who follow the teaching and learning process (Purwanto, 2011).

This research is considered important because in this pandemic era, learning is carried out online and the use of websites or e-learning is employed as the major medium. Hence, this research aimed at seeing the students' opinion on the use of websites during the online learning. 


\section{Method}

The research method used in this study was qualitative in nature. In conducting this research, the researcher used the qualitative approach. According to Kumar (2011), qualitative research involves the use of qualitative data and it focuses on interpretation of situations or phenomena in their natural settings. is a procedure of naturalistic quest that looks for deep comprehension of social phenomena inside their original setting. It centers around the reasons of why something happened rather than to what happen. The analysis depends solely on the immediate experiences of people as meaning-makers in the regular basis.

The subjects of this research are 17 students at Teuku Umar University. The instrument used was a set of questionnaire as shown below:

1. With learning using websites, learning becomes easier.

2. I am very courageous to study English with the implementation of learning using websites.

3. I can remember better while learning using websites because I can comeback at anytime I need.

4. Learning becomes more effective with the implementation of websites.

5. The implementation of learning using websites can enhance my ability to written texts.

6. The implementation of learning using websites can enhance my ability to spoken texts.

The questionnaire was answered in the form of 5 Likert scale indicating definitely agree (5), agree (4), neutral (3), disagree (2), and definitely disagree (1).

During the data collection, the students were given 60 minutes to answer the questions. And to enhance the data validity, the subjects were then interviewed using similar questions. This interview was used in regards of triangulation. Later, the data were analyzed usin interactive analysis which are data reduction, data display, and data verification.

\section{Results and Discussions}

The result is as shown below.

Table 1. Results

\begin{tabular}{|l|l|c|c|c|c|c|}
\hline No & \multicolumn{1}{|c|}{ Questioannire item } & $\begin{array}{c}\text { Definitely } \\
\text { Agree }\end{array}$ & Agree & neutral & Disagree & $\begin{array}{c}\text { Definitely } \\
\text { Disagree }\end{array}$ \\
\hline 1 & $\begin{array}{l}\text { With learning using } \\
\text { websites, learning } \\
\text { becomes easier. }\end{array}$ & 10 & 7 & 0 & 0 & 0 \\
\hline 2 & $\begin{array}{l}\text { I am very courageous to } \\
\text { study English with the } \\
\text { implementation of } \\
\text { learning using websites. }\end{array}$ & 14 & 3 & 0 & 0 & 0 \\
\hline 3 & $\begin{array}{l}\text { I can remember better } \\
\text { while learning using } \\
\text { websites because I can } \\
\text { comeback at anytime I } \\
\text { need. }\end{array}$ & 16 & 1 & 0 & 0 & 0 \\
\hline
\end{tabular}




\begin{tabular}{|l|l|c|c|c|c|c|}
\hline 4 & $\begin{array}{l}\text { Learning becomes more } \\
\text { effective with the } \\
\text { implementation of } \\
\text { websites. }\end{array}$ & 17 & 0 & 0 & 0 & 0 \\
\hline 5 & $\begin{array}{l}\text { The implementation of } \\
\text { learning using websites } \\
\text { can enhance my ability to } \\
\text { written texts. }\end{array}$ & 12 & 4 & 1 & 0 & 0 \\
\hline 6 & $\begin{array}{l}\text { The implementation of } \\
\text { learning using websites } \\
\text { can enhance my ability to } \\
\text { spoken texts. }\end{array}$ & 10 & 6 & 1 & 0 & 0 \\
\hline & & \multicolumn{5}{|c|}{ 17 students } \\
\hline
\end{tabular}

The table above shows that all of the respondents agree to the facts that using websites give them more positive effects. The diversity of website applications used by students is quite high. About half of the students have searched for information from websites that contain learning materials, usually post on website pages and write comments on information on website pages. Additionlly, most students are not used to looking for pictures of electrical components on web pages. Some students also answered they need more axercises on the websites. The frequency of using the website by students was quite high. Every time they search for learning materials from the website independently, almost half of the students need an average of one hour to two hours with a frequency of one to three times per week. Every time they search for learning materials from the website in groups, almost half of the students take 31 to 45 minutes, and almost half take more than 45 minutes. Almost half of them access the website one to three times per month to look for learning materials in groups. The role of researchers in learning is to control the activities of using the website by students. The students who had difficulty accessing the website and understanding the learning materials were given further explanation by the researcher. After getting an explanation, most of the students were able to do searching (using search engines), browsing and resourcing (using the website as a learning resource). However, students still have to be trained to use keywords specifically in the search process, use the restore command in the history menu, and use image media links.

Specific keywords used in the searching process will make it easier for students to obtain learning materials from the website. Furthermore, students must be accustomed to choosing learning materials that are relevant to the learning materials presented by the teacher in class. The application of the discussion method between students and between students and teachers in the classroom can be used as an activity to transfer information from the website to discussion participants. Knowledge that is growing rapidly can be transferred more easily through the use of websites in learning. The types of media and information contained on the website pages are published in both foreign and Indonesian languages. The use of foreign languages on the website can indirectly improve students' language skills. Although it does not actively improve language skills, it is suspected that the students' foreign language vocabulary will increase. The students will also be able to exchange information, especially through the process of posting on weblogs. Student activities in utilizing the website can also be intended for other purposes that are not related to learning, such as for communication via the web or publishing files on web pages. This activity can also prevent students from technological stuttering and get used to interacting with website-based content or media. The use of websites allows us to access and obtain 
information from text, graphics, images, photos, animations, audio and video. This research is only limited to using text and image media, so it is still less varied. Further research needs to be done using other types of media on the website so that it is expected to increase student attention and learning outcomes better. Pre-test data analysis shows that students have low initial cognitive abilities. After being given treatment by utilizing website-based learning media, learning outcomes have increased significantly. Even though there was an increase, most of the students got low learning outcomes.

The use of website-based learning media has a moderate effect on cognitive learning outcomes. Based on the regression equation, it is known that the effect of using websitebased learning media on cognitive learning outcomes is smaller than the influence of other factors. already on the web page. The students had been assigned to read it, but most of them did not read the learning material in its entirety. This indicates that the students' interest in reading is still quite low. Most students are not used to looking for and opening links to media images of electrical components on web pages so that they cannot answer test questions related to pictures of electrical components. Some students also did not do the assignments that the researchers gave. Some students did not show activities that were in line with the researchers' expectations because they were less active in learning. Based on the observations of researchers, these students are less motivated to learn even though they have been given treatment with website-based learning media. The researcher also suspects that website content, display and interactive media are needed that are more attractive to students so that they can grow their learning motivation. The interactive content, display and media allow students to see and hear learning materials, do assignments, practice questions, even exams and score lists. The important thing for further research is to involve learning motivation in addition to student learning outcomes.

\section{Conclusions}

From the result, it can be concluded that the students have positive response and positive expectation toward the use and advancement of lerning websites.

\section{References}

Furqan. (2012). Pengertian media pembelajaran dan ciri-ciri media pendidikan [Understanding learning media and characteristics of educational media]. Available at: http://furqanwera.blogspot.com/2012/12/pengertian-media-pembelajaran-dan-ciri.html [30 october 2021].

Kumar, R. (2011). Research methodology. SAGE Publisher.

Oetomo, B.S.D. et al. (2007). Pengantar teknologi informasi internet: Konsep dan aplikasi [Introduction to Internet Information Technology: Concepts and Applications.]. CV. Andi Offset.

Purwanto. (2011). Evaluasi hasil belajar [Evaluation of learning results]. Pustaka Pelajar.

Rusman.et al. (2012). Pembelajaran berbasis teknologi informasi dan komunikasi [Information and communication technology-based learning]. PT. Rajagrafindo Persada. Sahid. (2010). Pengembangan media pembelajaran berbasis ICT [Development of ICTbased learning media]. Available at:http://staff.uny.ac.id/sites/default/files/131930136/PengembanganMedia Pembelajaran Berbasis ICT.pdf [26 April 2013]. 
Susanti, W., \& Oriniati, P. (2020). Analisis website e-learning berbasis standar SCORM content aggregation model 2.1di Fakultas Ilmu Komputer Universitas Bandar Lampung [Analysis of e-learning website based on SCORM content aggregation standard 2.1 at faculty of computer science University Bandar Lampung]. Expert-Jurnal Manajemen Sistem Informasi Dan Teknologi, 2(3), 43-50.

Syaputri, V. N., Idami, Z., \& Ismail, N. M. (2020). Online Teaching and Teachers' Mental Burdens during the COVID-19 Pandemic. Proceeding of the 3rd International Conference on Multidisciplinary Research, 3(1), 109-114.

Warsita, B. (2008). Teknologi pembelajaran: Landasan dan aplikasinya [Learning technologies: Their foundations and applications]. Rineka Cipta. 